\title{
Oxidation of Volatile Organic Compounds by Highly Efficient Metal Zeolite Catalysts
}

\author{
Olívia S. G. P. Soares, ${ }^{[a]}$ António M. Fonseca, ${ }^{[b, c]}$ Pier Parpot, ${ }^{[b, c]}$ José J. M. Órfão, ${ }^{[a]}$ \\ Manuel F. R. Pereira, ${ }^{*[a]}$ and Isabel C. Neves* ${ }^{*[b, c]}$
}

The presence of two metals $\left(\mathrm{M}^{1} \mathrm{M}^{2}\right)$ in a zeolite structure enhances the degradation of pollutants in liquid or gas phase comparing to monometallic catalysts. In this work, the complete oxidation of ethyl acetate into $\mathrm{CO}_{2}$ was achieved by metal catalysts based on $\mathrm{NaY}$ zeolite prepared by the ion-exchange method. The metal zeolite catalysts were optimized by using several parameters: (i) the presence of a second metal in $M^{1} M^{2}$ catalysts; (ii) the presence or not of a noble metal in the pair
$\mathrm{CuM}^{2}\left(\mathrm{M}^{2}=\mathrm{Pd}, \mathrm{Zn}\right.$ or $\left.\mathrm{Ag}\right)$; (iii) the order of introduction of the metals in $\mathrm{M}^{1} \mathrm{M}^{2}$ catalysts (CuPd or PdCu); (iv) particle size of $\mathrm{NaY}$ and $\mathrm{NaY}_{\text {nano; }}$ and $(\mathrm{v})$ the effect of simultaneously adding metal species ( $\mathrm{Cu}$ and $\mathrm{Pd}) . \mathrm{M}^{1} \mathrm{M}^{2}$ catalysts presented the best results compared to the monometallic catalysts and the presence of a noble metal in $M^{1} M^{2}$ catalysts enhanced their acivity. Among the metal phases studied, the catalyst $(\mathrm{CuPd})_{0.01}-\mathrm{Y}$ has shown to be the most efficient for this application.

\section{Introduction}

Volatile organic compounds (VOCs) are dangerous pollutants to human health and the environment and they are one of the major sources of air pollution. ${ }^{[1,2]}$ Catalytic oxidation has emerged as a promising environmentally friendly technology for VOC abatement due to the use of lower temperatures (circa $250-00^{\circ} \mathrm{C}$ ) as compared to conventional thermal oxidation that requires significantly higher temperatures $\left(650-1100^{\circ} \mathrm{C}\right) .^{[1]}$

Catalytic oxidation has been widely studied for the abatement of VOCs, and two major types of catalysts can be used in the catalytic oxidation of VOCs: supported noble metals ${ }^{[3-5]}$ or metal oxides. ${ }^{[5-7]}$ The most regularly used catalysts are supported noble metals ( $\mathrm{Pt}$ or $\mathrm{Pd}$ ), which are generally considered to be more active than metal oxides and to be structure sensitive depending on the metal particle size, preparation method and supported metal. ${ }^{[1,3-7,8]}$

[a] Dr. O. S. G. P. Soares, Prof. Dr. J. J. M. Órfão, Prof. Dr. M. F. R. Pereira Laboratório de Catálise e Materiais (LCM)

Laboratório Associado LSRE/LCM

Universidade do Porto

Rua Dr. Roberto Frias

Porto 4200-465 (Portugal)

E-mail: fpereira@fe.up.pt

[b] Prof. Dr. A. M. Fonseca, Prof. Dr. P. Parpot, Prof. Dr. I. C. Neves

CQUM - Centro de Química

Universidade do Minho

Campus de Gualtar

Braga 4710-057 (Portugal)

E-mail: ineves@quimica.uminho.pt

[c] Prof. Dr. A. M. Fonseca, Prof. Dr. P. Parpot, Prof. Dr. I. C. Neves

CEB - Centre of Biological Engineering

Universidade do Minho

Campus de Gualta

Braga 4710-057 (Portugal)

Supporting information for this article is available on the WWW under https://doi.org/10.1002/cctc.201800524

This manuscript is part of a Special Issue on the "Portuguese Conference on Catalysis" based on the International Symposium on Synthesis and Catalysis (ISySyCat).
Noble or transition metals introduced by the ion-exchange method on zeolite structures have excellent catalytic properties in the oxidation of VOCs. ${ }^{[9-12]}$ Also, these structures themselves are good catalysts to be used in VOC oxidation. H-BEA zeolite was used in the catalytic oxidation of 1,2-dichloroethane to evaluate catalyst performance along successive reaction-regeneration cycles. The results showed that the initial conversion of the original catalyst is re-established after each regeneration step. $^{[13]}$

The characteristics as shape selectivity, pore structure, ion exchange capacity, acidity and thermal stability bring to the zeolites their remarkable catalytic properties. These structures are solid hydrated crystalline materials with an open structure framework containing several channels and pores with regular dimensions occupied by cations and water molecules. These cations balance the net negative charge of the zeolite framework and due to their mobility, since they are not bound covalently, they can be reversibly exchanged for other cations by a simple ion exchange reaction. ${ }^{[14,15]}$ This property, joined with the size and shape characteristics of the zeolite structures, allows these materials to be used as an effective catalyst in several reactions. ${ }^{[9-15]}$ In addition, these structures are cheap raw materials and their use is widespread in the industry. ${ }^{[14,15]}$

In the zeolites commonly used for the catalytic oxidation, the faujasite (FAU) structure is the most chosen. Magnoux et al. ${ }^{[12]}$ studied the catalytic oxidation of isopropanol and oxylene over basic NaX zeolite and concluded that the performance of this synthetic analogue of faujasite was limited by its pore structure. The catalytic oxidation of butyl acetate over silver-loaded ( $\mathrm{HY}$ and HZSM-5) zeolites was investigated and the best catalyst was AgY due to better metal dispersion, surface characteristics and acidity, and its pore system. ${ }^{[11]}$ Likewise, Silva et al. ${ }^{[16]}$ studied the applicability of the FAU (Y) and MFI (ZSM5) zeolite structures in the biosorption of $\mathrm{Cr}(\mathrm{VI})$ and showed that the resulting $\mathrm{Cr}$-zeolite materials are active catalysts for the complete oxidation of ethyl acetate. ${ }^{[17,18]} \mathrm{Cr}$ - 
$\mathrm{NaY}$ catalysts showed the following sequence in the selectivity to $\mathrm{CO}_{2}$ after conversion of ethyl acetate $>$ toluene $>$ ethanol. ${ }^{[18]}$

In all different zeolite structures, the faujasite zeolite shows high thermal and chemical stability and it is characterized by low Si/Al ratio, which justifies its higher cation exchange capacity. ${ }^{[19]}$ The negative charge of the faujasite framework can be compensated by the introduction of more than one metal into the structure and its location will depend on the available sites. ${ }^{[19,20]}$ These cations exchanged are preferentially located in the hexagonal prisms (site I), in the sodalite cages (site $\mathrm{I}^{\prime}$ and II') or in the supercages (sites II, III and III') of the framework. ${ }^{[19-21]}$ Figure 1 presents such sites on the framework of the zeolite $\mathrm{Y}^{[21]}$

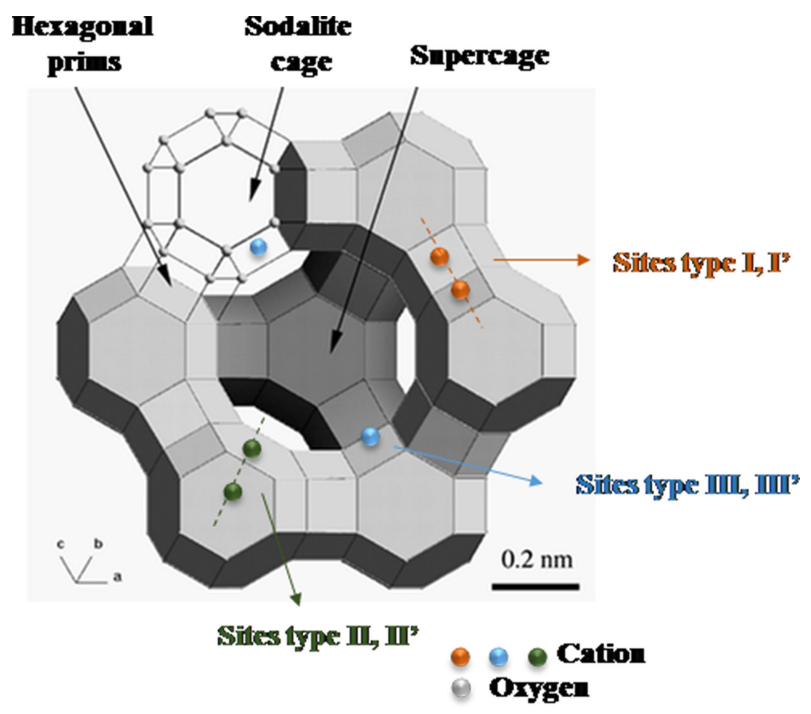

Figure 1. Framework structure of zeolite $Y$ (adapted from [21]).

The cation positions depend on the type and the amount of the cations used and their hydration state..$^{[19,20]}$ Obviously, the location of the cations in the structure will affect the catalytic properties of the zeolite.

Recently, it was confirmed that the introduction of two metals in the framework of the zeolite $Y$ enhanced their catalytic properties in liquid phase. ${ }^{[22,23]}$ In the catalytic nitrate reduction in water, the best catalyst was the pair CuPd prepared by the ion-exchange method, which allowed $100 \%$ nitrate conversion with selectivity to nitrogen as high as $94 \%$ under the conditions tested. ${ }^{[22]}$ Remarkable, in the bromate reduction in water, the same catalyst $\mathrm{CuPd}-\mathrm{Y}$ displayed the best catalytic results. ${ }^{[23]}$

In the present work, we want to verify if these metal zeolite catalysts previously tested with success in liquid phase applications are also efficient for the removal of VOCs from a gaseous stream. With this in mind, we studied in detail the catalytic oxidation of ethyl acetate as model compound of VOCs over monometallic $(M)$ and bimetallic $\left(M^{1} M^{2}\right)$ catalysts based on $\mathrm{NaY}$ zeolite prepared by the ion-exchange method with copper, palladium, zinc and silver as metal ions, with copper being the common cation in all $\mathrm{M}^{1} \mathrm{M}^{2}$ catalysts. In several industrial processes, the ester compound ethyl acetate is present as a typical VOC pollutant and it is emitted into the atmosphere without prior further purification. ${ }^{[2]}$ To the best of our knowledge, no previous work has been found in the literature comparing the catalytic oxidation of ethyl acetate over several mono and bimetallic catalysts based on $\mathrm{NaY}$ zeolite.

\section{Results and Discussion}

The catalytic performance of all metal zeolite catalysts was evaluated in the catalytic oxidation of ethyl acetate. A systematic study was performed to select the best catalyst. As such, different parameters were studied: the effect of the presence of the second metal in $\mathrm{M}^{1} \mathrm{M}^{2}$ catalysts; the order of introduction of the metals in the pair copper with palladium; the presence or absence of the noble metal in the pair $\mathrm{CuM}^{2}\left(\mathrm{M}^{2}=\mathrm{Pd}, \mathrm{Zn}\right.$ or $\mathrm{Ag}$ ); the size of particles of the parent zeolites; the concentration of the precursor used to introduce the second metal in the monometallic zeolite catalysts and the effect of adding $\mathrm{Cu}$ and Pd simultaneously to the structure of the zeolite $\mathrm{NaY}$.

Several mono $(M)$ and bimetallic $\left(M^{1} M^{2}\right)$ zeolite catalysts used in this work were characterized by different techniques and the details of their preparation and characterization are available in previous works. ${ }^{[22,23,25,26]}$ In this work, the samples were characterized by infrared spectroscopy (FTIR), nitrogen $\left(\mathrm{N}_{2}\right)$ adsorption at $-196^{\circ} \mathrm{C}$, temperature programmed reduction (TPR) and chemical analysis.

The characteristic strong bands attributed to the vibrational modes from the zeolite structure ${ }^{[22,23,26]}$ were identified in all FTIR spectra of metal zeolite catalysts and they are very similar to the parent zeolites (Figure S1 shows the FTIR spectra of M and $\mathrm{M}^{1} \mathrm{M}^{2}$ zeolite catalysts based in $\mathrm{Cu}$ and $\mathrm{Pd}$ ). Likewise, after the introduction of the metals in the zeolite structure, the sensitive vibrations bands of the zeolite did not shift or broaden, confirming that the ion-exchange method used did not lead to significant modifications in the zeolite structure. This analysis can also be used to determine the framework Si/Al ratio using the bands corresponding to the lattice vibrations of the zeolite structure $\left(570\right.$ to $600 \mathrm{~cm}^{-1}$ ). ${ }^{[27]}$

Table 1 summarizes the results obtained from the characterization of the samples.

FTIR results confirmed that the ion-exchange method caused some decrease in the framework $\mathrm{Si} / \mathrm{Al}$ ratios. As expected, the heat treatments performed in $M^{1} M^{2}$ catalysts, affects this ratio. The same behavior was observed for the antimicrobial materials based in zeolites prepared by the ionexchange method. ${ }^{[26]}$

All metal zeolite catalysts prepared with $\mathrm{NaY}$ reveal a Type-I isotherm as was confirmed by $\mathrm{N}_{2}$ adsorption results, characteristic of solids with a microporous structure. Although the catalysts based on $\mathrm{NaY}_{\text {nano, }}$ display a Type-IV isotherm, according to the IUPAC classification, indicating that in addition to microporous, this zeolite contains an important amount of mesoporous, most probably resulting from the free space in the agglomerates of small particles of $\mathrm{NaY}_{\text {nano. }}{ }^{[23]}$ 
Table 1. Characterization results of the parent zeolites and $M$ and $M^{1} M^{2}$ catalysts prepared by the ion-exchange method.

\begin{tabular}{|c|c|c|c|c|}
\hline Samples & $\mathrm{Si} / \mathrm{Al}^{[\mathrm{a}]}$ & $M[w t \%]^{[b]}$ & $\mathrm{M} / \mathrm{Cu}^{[\mathrm{c}]}$ & $\mathrm{S}_{\mathrm{BET}}\left[\mathrm{m}^{2} / \mathrm{g}\right]^{[\mathrm{d}]}$ \\
\hline $\mathrm{NaY}$ & 2.82 & - & - & 792 \\
\hline $\mathrm{NaY}_{\text {nano }}$ & 2.30 & - & - & 643 \\
\hline $\mathrm{Cu}-\mathrm{Y}$ & 2.97 & $0.60(\mathrm{Cu})$ & - & 708 \\
\hline CuPd-Y & 2.87 & $\begin{array}{l}0.64(\mathrm{Cu}) \\
1.80(\mathrm{Pd})\end{array}$ & 1.68 & 684 \\
\hline $\mathrm{CuPd}_{0.02}-\mathrm{Y}$ & 2.84 & $\begin{array}{l}0.72(\mathrm{Cu}) \\
2.36(\mathrm{Pd})\end{array}$ & 1.95 & 351 \\
\hline$(\text { CuPd })_{0.01}-Y$ & 2.75 & $\begin{array}{l}0.87(\mathrm{Cu}) \\
1.78(\mathrm{Pd})\end{array}$ & 1.19 & 644 \\
\hline$P d-Y$ & 2.87 & $0.92(\mathrm{Pd})$ & - & 705 \\
\hline $\mathrm{PdCu}-\mathrm{Y}$ & 2.70 & $\begin{array}{l}1.60(\mathrm{Pd}) \\
0.84(\mathrm{Cu})\end{array}$ & 1.14 & 616 \\
\hline $\mathrm{PdCu}_{0.02}-\mathrm{Y}$ & 2.71 & $\begin{array}{l}1.03(\mathrm{Pd}) \\
1.37(\mathrm{Cu})\end{array}$ & 0.45 & 344 \\
\hline $\mathrm{CuAg}-\mathrm{Y}$ & 2.66 & $\begin{array}{l}1.02(\mathrm{Cu}) \\
1.25(\mathrm{Ag})\end{array}$ & 0.72 & 607 \\
\hline $\mathrm{CuZn} \mathrm{n}_{0.05}-\mathrm{Y}$ & 2.75 & $\begin{array}{l}0.96(\mathrm{Cu}) \\
3.16(\mathrm{Zn})\end{array}$ & 3.20 & 342 \\
\hline $\mathrm{Cu}-\mathrm{Y}_{\text {nano }}$ & 2.35 & $0.74(\mathrm{Cu})$ & - & 360 \\
\hline CuPd $-Y_{\text {nano }}$ & 2.31 & $1.72(\mathrm{Pd})$ & 1.27 & 330 \\
\hline
\end{tabular}

[a] Framework $\mathrm{Si} / \mathrm{Al}$ ratio determined from FTIR analysis using the formula $\mathrm{Si} / \mathrm{Al}=[(1 / \chi)-1]$, where $\chi=3.857-0.00621 \times \omega_{D R}$ and $\omega_{D R}$ is the zeolite specific double ring vibration mode between 570 and $600 \mathrm{~cm}^{-1,[26]}$ [b] metal loading obtained by ICP analysis; ${ }^{[22,23]}[\mathrm{c}]$ atomic ratio of $\mathrm{M} / \mathrm{Cu}$ where $\mathrm{M}$ is $\mathrm{Pd}, \mathrm{Zn}$ or $\mathrm{Ag}$; [d] surface area obtained from nitrogen adsorption isotherms by the BET method.

The BET surface areas $\left(\mathrm{S}_{\mathrm{BET}}\right)$ were calculated by the BET equation. $\mathrm{NaY}$ presents a larger surface area than $\mathrm{NaY}_{\text {nano }}$ (Figure $\mathrm{S} 2$ shows the $\mathrm{N}_{2}$ adsorption isotherm of the parent zeolites). For all metal zeolite catalysts, a decrease in the surface area after ion-exchange treatment was observed when compared to the parent zeolites. In addition, $\mathrm{M}^{1} \mathrm{M}^{2}$ catalysts exhibit larger decreases in the surface area being mainly important for the catalysts with higher amounts of metals.

The metal contents present on the catalysts were quantified by ICP and are also displayed in Table 1. The lower metal amount was observed for the monometallic catalysts with $0.60 \mathrm{wt} \%$ and $0.92 \mathrm{wt} \%$ for copper and palladium, respectively. In $\mathrm{M}^{1} \mathrm{M}^{2}$ catalysts based in copper and palladium, the metal amount was shifting between 0.64 to 0.81 wt \% for copper, and 1.80 to $2.87 \mathrm{wt} \%$ for palladium in the pairs CuPd, and 0.84 to $1.37 \mathrm{wt} \%$ for copper and 1.03 to $1.60 \mathrm{wt} \%$ for palladium in the pairs $\mathrm{PdCu}$. The higher amount detected for zinc in the pair CuZn was due to the higher concentration of the metal salt $(0.05 \mathrm{M})$ used for preparing this $\mathrm{M}^{1} \mathrm{M}^{2}$ catalyst. ${ }^{[26]}$ However, the metal/copper atomic ratio in the bimetallic catalysts was almost 2.0 for the catalysts with the presence of the noble metal, for the pair CuPd when prepared with the Pd concentration of $0.02 \mathrm{M}$.

Since the ion-exchange reaction in the zeolites is not essentially a surface reaction but occurs in the whole structure, the bulk phase, the metal ion species are expected to occupy several positions (Figure 1) were the cations exchanged are positioned to compensate the negative charge of the framework. ${ }^{[19-21]}$ From the literature, dealing with the ion-exchange with a distinct metal cation as $\mathrm{Cu}^{2+}$ or $\mathrm{Zn}^{2+}$, these ions occupy preferentially the sites $\mathrm{I}^{\prime}$ and $I \mathrm{I}^{[19,20,26]}$ Probably, the same is observed for $\mathrm{Pb}^{2+}$ ion since its ionic radius $(0.78 \AA)$ is close to $\mathrm{Zn}^{2+}(0.74 \AA)$ and $\mathrm{Cu}^{2+}(0.69 \AA)$ ions. For $\mathrm{M}^{1} \mathrm{M}^{2}$ catalysts, in the second ion-exchange, the metal ions will occupy the sites vacant as sodalite and supercages cavities, which are more available for the catalytic reaction. In the case of $\mathrm{Ag}^{+}$ion, the ionic radius is $1.14 \AA$ and is expected to occupy preferentially the sites of sodalite and the supercages. ${ }^{[19-21,26]}$

Figure 2 shows the TPR results of the different metal zeolite catalysts. $\mathrm{M}$ catalysts based on $\mathrm{NaY}$ show peaks with maxima

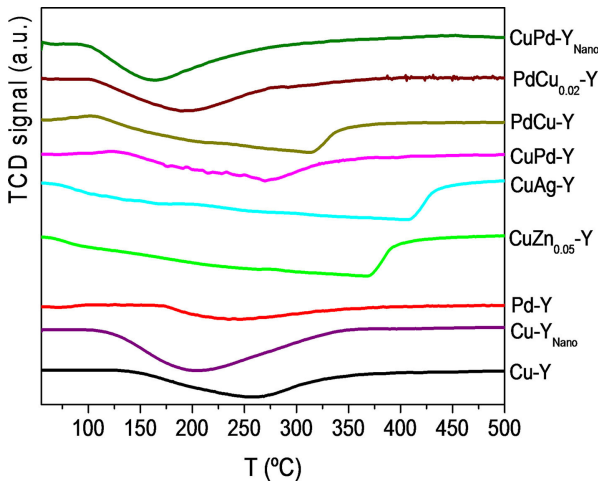

Figure 2. TPR profiles of the metal zeolite catalysts based on $\mathrm{NaY}$ or $\mathrm{NaY}_{\text {nano. }}$.

around $230^{\circ} \mathrm{C}$ for $\mathrm{Pd}$ and $260^{\circ} \mathrm{C}$ for $\mathrm{Cu}$, whereas the peak of $\mathrm{Cu}$ for $\mathrm{NaY}_{\text {nano }}$ appears at $205^{\circ} \mathrm{C}$. Pd is well dispersed since the reduction peak attributed to the decomposition of $\mathrm{Pd} \beta$-hydride (around $60^{\circ} \mathrm{C}$ ) was not observed. ${ }^{[28,29]} \mathrm{All} \mathrm{M}^{1} \mathrm{M}^{2}$ catalysts show a single reduction peak, for $\mathrm{PdCu} \mathrm{Cu}_{0.02}-\mathrm{Y}$ and $\mathrm{CuPd}-\mathrm{Y}_{\text {nano, }}$ it appears at lower temperatures than for the monometallic catalysts, the opposite being observed for $\mathrm{CuPd}-\mathrm{Y}$ and $\mathrm{PdCu}-\mathrm{Y}$ with reduction peaks at 275 and $300^{\circ} \mathrm{C}$, respectively. The increase in the reduction temperature for these bimetallic catalysts indicates that $\mathrm{Pd}$ and $\mathrm{Cu}$ species are in close contact in the zeolite structure. The TPR profiles of the catalysts clearly show that the order of ion exchange of the metals has influence in the reduction temperature. The catalysts with silver and zinc present the highest reduction temperatures.

The catalytic performance of the metal zeolite catalysts was evaluated in the oxidation of ethyl acetate. An experiment using only the parent NaY zeolite was also carried out for comparative purposes. The light-off curves consisted in two cycles of increasing temperature, keeping the temperature constant for $1 \mathrm{~h}$ and decreasing it. It was observed that the catalytic performance in the first and second cycle was quite similar indicating that the catalyst is stable for this reaction. The performance of all catalysts was always compared using the decreasing temperature step.

Figure 3 shows the light-off curves for ethyl acetate oxidation over metal zeolite catalysts prepared with $\mathrm{NaY}$.

Accordingly, it can be observed that ethyl acetate is only completely oxidized into $\mathrm{CO}_{2}$ at 342,355 and $392^{\circ} \mathrm{C}$, respectively, with $\mathrm{PdCu}-\mathrm{Y}, \mathrm{CuPd}-\mathrm{Y}$ and $\mathrm{Pd}-\mathrm{Y}$ catalysts. The parent $\mathrm{NaY}$ zeolite allows oxidizing only $35 \%$ of the $\mathrm{VOC}$ into $\mathrm{CO}_{2}$ at $500^{\circ} \mathrm{C}$. 


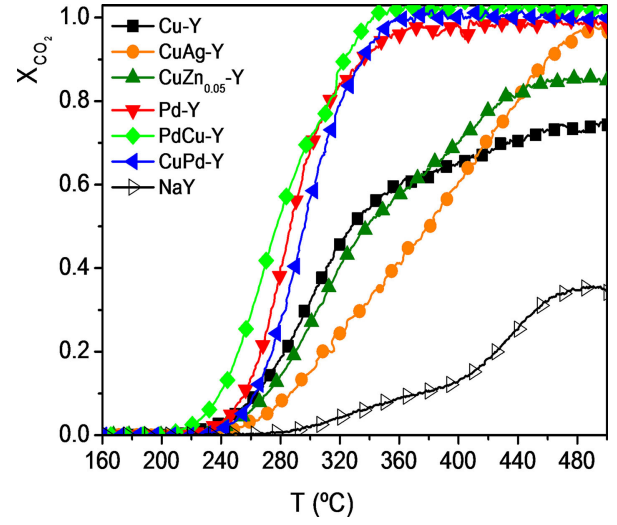

Figure 3. Light-off curves for the oxidation of ethyl acetate (inlet concentration of $4000 \mathrm{mgC} / \mathrm{m}^{3}$ ) over metal zeolite catalysts based on $\mathrm{NaY}$.

The presence of $\mathrm{Pd}$ markedly decreases the temperature to achieve $50 \%$ of $\mathrm{CO}_{2}$ conversion $\left(\mathrm{T}_{50}\right)$ and principally to achieve total oxidation of ethyl acetate into $\mathrm{CO}_{2}$. The parent $\mathrm{NaY}$ zeolite presents a light-off curve with two levels where the conversion into $\mathrm{CO}_{2}$ remains almost constant, the first between 370 and $400^{\circ} \mathrm{C}$ and the second starting at $465^{\circ} \mathrm{C}$. The shape of this curve is an indication of the formation and further oxidation of by-products. ${ }^{[17]}$ The catalytic activity of the parent zeolite must be related to the surface acid sites that could absorb and activate ethyl acetate and/or oxygen molecules. ${ }^{[30]}$

The presence of metals in $\mathrm{NaY}$ increases not only the performance of the catalyst, but also changes the reaction pathways since in these catalysts the presence of difference levels is not noticed. It has been reported that the catalytic oxidation of ethyl acetate occurs through several consecutive and/or parallel steps, where ethyl acetate is decomposed into smaller organic molecules, such as ethanol and/or ethylene or partially oxidized to acetaldehyde or acetic acid and then these products are completely oxidized to $\mathrm{CO}_{2}$ and $\mathrm{H}_{2} \mathrm{O} .^{[17,31]}$ In this work, it was not possible to identify the by-products formed since the VOC analyzer only allows the measurement of the total amount of VOC. The performance of the metal zeolite catalysts based on NaY (Figure 3) shows to be highly dependent on the type of metal exchanged during the catalytic oxidation of ethyl acetate. The highest performance was observed for the catalysts with $\mathrm{Pd}, \mathrm{PdCu}-\mathrm{Y}$ being the catalyst that allows the ethyl acetate oxidation at lower temperatures. It should be highlighted that the presence of Cu does not have a significant impact in the catalytic activity of the $\mathrm{Pd}-\mathrm{Y}$ catalyst, but its order of exchange influences the catalyst performance. The introduction of $\mathrm{Cu}$ as second metal enhances, while as first metal slightly decreases the catalytic performance of the $\mathrm{Pd}-\mathrm{Y}$ catalyst. The elemental composition of the prepared catalysts (Table 1) showed that the sequential ion-exchange method leads to different contents of the metals due to different interactions between the zeolite lattice and the cations, and consequently, the metal ions will occupy different sites on the sodalite and supercages. Effectively, by FTIR analysis it was observed that the Si/Al ratio slightly decreases with the introduction of the second metal. As indicated previously, it was observed that all catalysts were stable, presenting similar performances in the reaction cycles. Brayner et al. ${ }^{[32]}$ reported that the addition of $\mathrm{Cu}$ to $\mathrm{Pd}$ catalysts supported on niobium decreases the catalysts deactivation during the oxidation of ethanal.

The addition of $\mathrm{Ag}$ or $\mathrm{Zn}$ to the $\mathrm{Cu}-\mathrm{Y}$ catalysts does not improve significantly the oxidation of ethyl acetate. As shown in Table 1, the addition of $\mathrm{Ag}$ increases the $\mathrm{T}_{50}$ into $\mathrm{CO}_{2}$ from 318 to $370^{\circ} \mathrm{C}$, but it allows $95 \%$ of ethyl acetate oxidation into $\mathrm{CO}_{2}$, while with the $\mathrm{Cu}-\mathrm{Y}$ catalyst only $77 \%$ of ethyl acetate is oxidized into $\mathrm{CO}_{2}$ at $500^{\circ} \mathrm{C}$. Jodaei et al. ${ }^{[33]}$ observed that the incorporation of $\mathrm{Ag}$ on $\mathrm{HZSM}-5$ zeolite improves significantly the ethyl acetate conversion obtaining $100 \%$ of conversion at $350^{\circ} \mathrm{C}$. Additionally, they also observed that the addition of transition metals ( $\mathrm{Fe}, \mathrm{Mn}, \mathrm{Co}$ ) enhances the catalytic performance of the Ag-HZSM-5. On the other hand, the addition of $\mathrm{Zn}$ only improves the oxidation to $85 \%$. The low catalytic performance of the $\mathrm{Ag}$ and $\mathrm{Zn}$ containing catalysts when compared to $\mathrm{Pd}$ catalysts could be related to their low reducibility (see Figure 2).

The results obtained with the $\mathrm{Cu}$ catalysts revealed that $\mathrm{Cu}$ loaded on $\mathrm{NaY}$ (Figure 3) presents significantly higher activity into $\mathrm{CO}_{2}$ than those prepared with $\mathrm{NaY}_{\text {nano }}$ (Figure 4). The

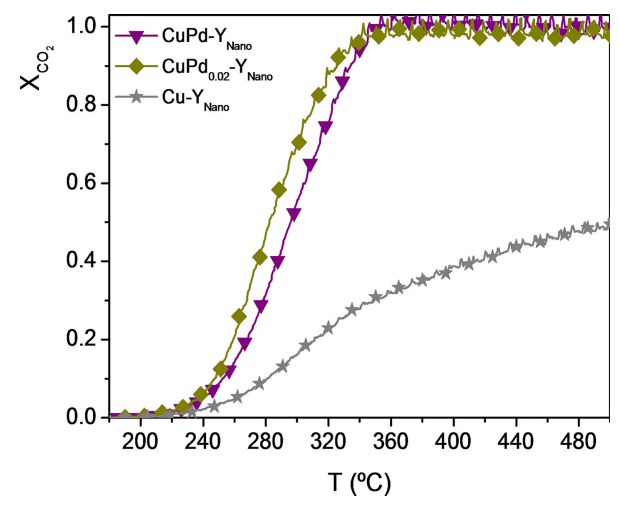

Figure 4. Light-off curves for the oxidation of ethyl acetate (inlet concentration of $4000 \mathrm{mgC} / \mathrm{m}^{3}$ ) over metal zeolite catalysts based on $\mathrm{NaY}_{\text {nano. }}$.

temperatures of $50 \%$ of ethyl acetate conversion into $\mathrm{CO}_{2}$ (Table 2) were $318^{\circ} \mathrm{C}$ for the $\mathrm{Cu}-\mathrm{Y}$ catalyst and $500^{\circ} \mathrm{C}$ for the $\mathrm{Cu}-\mathrm{Y}_{\text {nano, }}$ although the highest total conversion was obtained with the latter catalyst. Comparing the results obtained with the two parent zeolites, it can be concluded that the highest catalytic performance to convert ethyl acetate to $\mathrm{CO}_{2}$ observed for $\mathrm{NaY}$ is related to its higher surface area (see Table 1), since the amount of metal is similar in both parent zeolites.

Figure 4 also shows that the $\mathrm{CuPd}-\mathrm{Y}_{\text {nano }}$ catalyst presents lower activity than the CuPd-Y (see Figure 3), confirming that the structure of the zeolite affects the catalytic performance. Since the content of metals is similar in both zeolites, the different performance must be related to the surface area. For the CuPd catalysts based on $\mathrm{NaY}_{\text {nanor }}$ it can be observed, illustrated in Figure 4, that $\mathrm{CuPd}_{0.02}-\mathrm{Y}_{\text {nano }}$ performs slightly better than $\mathrm{CuPd}-\mathrm{Y}_{\text {nano. }}$. 
Table 2. Catalytic performances of the catalysts expressed as function of the temperature required to achieve $50 \%$ and $90 \%$ conversions of ethyl acetate into $\mathrm{CO}_{2}\left(\mathrm{~T}_{50}\right.$ and $\left.\mathrm{T}_{90}\right)$.

\begin{tabular}{lll|} 
Samples & $\mathrm{T}_{50}\left[{ }^{\circ} \mathrm{C}\right]$ & $\mathrm{T}_{90}\left[{ }^{\circ} \mathrm{C}\right]$ \\
\hline $\mathrm{Cu}-\mathrm{Y}$ & 318 & - \\
$\mathrm{CuAg}-\mathrm{Y}$ & 370 & 459 \\
$\mathrm{CuZn}$ & 326 & - \\
$\mathrm{Pd}-\mathrm{Y}$ & 286 & 334 \\
$\mathrm{PdCu}-\mathrm{Y}$ & 276 & 324 \\
$\mathrm{CuPd}-\mathrm{Y}$ & 296 & 335 \\
$\mathrm{CuPd}-\mathrm{Y}_{\text {Nano }}$ & 277 & 313 \\
$\mathrm{CuPd}$ & 287 & 318 \\
$\mathrm{CuY}_{\text {Nano }}-\mathrm{Y}_{\text {Nano }}$ & 500 & - \\
$\left(\mathrm{CuPd}_{0.01}-\mathrm{Y}\right.$ & 265 & 298 \\
$\mathrm{PdCu}_{0.02}-\mathrm{Y}$ & 267 & 307 \\
$\mathrm{CuPd}_{0.02}-\mathrm{Y}$ & 272 & 309 \\
\hline
\end{tabular}

Since both catalysts present comparable surface area, this fact must be related to the higher amount of metals of the former.

The effect of metal amounts and exchange order was also evaluated for the $\mathrm{PdCu}$ pair ion-exchanged on $\mathrm{NaY}$ zeolite since it presented the best results. Contrarily to that observed for the catalysts exchanged with the same amount of metals (Figure 3), for which the order of metals during the ion-exchange method has some influence in the catalytic performance; it was observed (Figure 5) that when higher amount of metals is

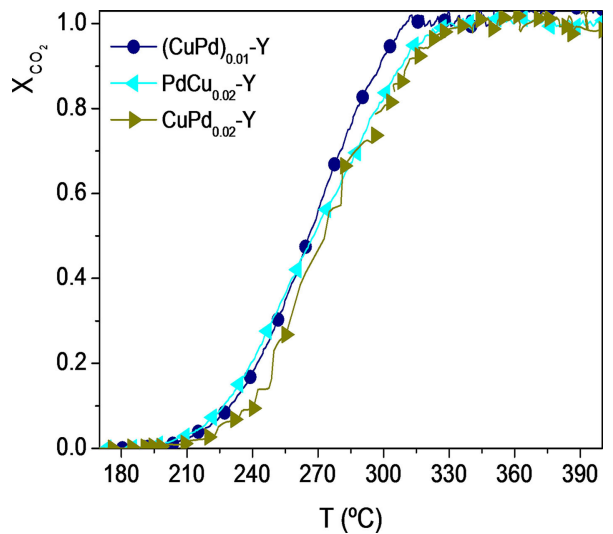

Figure 5. Light-off curves for the oxidation of ethyl acetate (inlet concentration of $4000 \mathrm{mgC} / \mathrm{m}^{3}$ ) over $\mathrm{Pd} / \mathrm{Cu}$ bimetallic zeolite catalysts based on $\mathrm{NaY}$

exchanged, the order of exchange of the metals practically has no influence in the catalytic performance.

Furthermore, it was also observed that the catalytic activity increases with the increase of the metal content independently of the metal. Jablonska et al. [30] observed that the catalytic performance during the oxidation of methanol was practically the same increasing the $\mathrm{Pd}$ content in $\mathrm{Pd} / \mathrm{NaY}$ catalysts from 0.5 to $1.0 \mathrm{wt} \%$, the catalytic performance being only significantly enhanced when the loading increase to $1.5 \mathrm{wt} \%$, decreasing thereafter with the increase of the Pd content. On the other hand, the catalyst $(\mathrm{CuPd})_{0.01}-\mathrm{Y}$, where the metals were ion-exchanged at same time, present the best performance among all the catalysts tested in this work. This catalyst presents a similar amount of metals compared to $\mathrm{CuPd}-\mathrm{Y}$ and $\mathrm{PdCu}-\mathrm{Y}$ and a surface area like the one obtained for those catalysts (see Table 1). Due to the simultaneous ion-exchange of metals the interaction between the zeolite lattice and the cations could favor the oxidation of ethyl acetate. Since the cations in sites II and III are more exposed and accessible (Figure 1), when the metals are added simultaneously, they occupy these positions favoring their performance for the oxidation of ethyl acetate. Thus, confirming that the VOC oxidation over noble metal catalysts is structure sensitive, depending on the metal particle size and preparation method. $^{[3,8]}$

A long-term experiment was carried out over the sample with the highest catalytic performance to analyze the stability of this catalyst $\left((\mathrm{CuPd})_{0.01}-\mathrm{Y}\right)$. The conversion of ethyl acetate into $\mathrm{CO}_{2}$ at $300^{\circ} \mathrm{C}$ as a function of time is shown in Figure 6 .

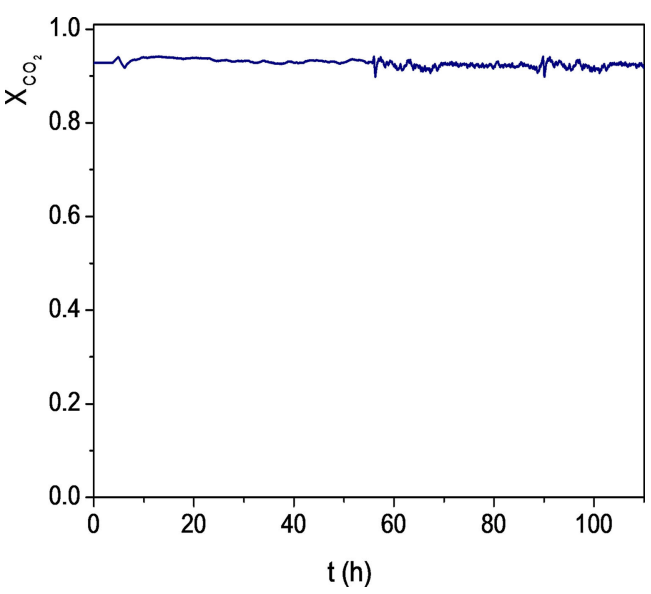

Figure 6. Evolution of the conversion of ethyl acetate into $\mathrm{CO}_{2}$ at $300^{\circ} \mathrm{C}$ with time using the $(\mathrm{CuPd})_{0.01}-\mathrm{Y}$ catalyst.

The reaction temperature was selected to achieve a high initial VOC conversion of about $90 \%$.

It was observed that the catalyst remains stable up to $110 \mathrm{~h}$ of reaction, showing a conversion of around $90 \%$ during the entire experiment.

This work confirms that the pair CuPd ion exchanged on zeolite structures is a very versatile catalyst, showing high performances to eliminate pollutants not only by reduction in liquid phase, as showed in previous works, ${ }^{[22,23,25]}$ but also by oxidation in the gas phase.

\section{Conclusions}

Metal zeolite catalysts were successfully prepared by the ionexchange method over $\mathrm{NaY}$ or $\mathrm{NaY}_{\text {nano }}$ to be used as catalysts in the ethyl acetate oxidation. The ion-exchange method produced good metal dispersions without significant changes in the crystalline structure of the parent zeolites. The presence of palladium remarkably increases the performance of the parent 
zeolites, allowing a total oxidation of ethyl acetate into $\mathrm{CO}_{2}$. The order of metal exchange has some influence in the catalytic performance only for low amounts of metals supported. The best results were obtained when the metals were exchanged at the same time due to the interaction between the zeolite lattice and the metal cations. The metal zeolite catalysts described in this work are very versatile and can be used to eliminate selected pollutants, either in the liquid or gas phase.

\section{Experimental Section}

\section{Materials and Reagents}

Two commercial NaY zeolites with different particle sizes in sodium form and as powder; $\mathrm{NaY}$ zeolite (CBV100, $\mathrm{Si} / \mathrm{Al}=2.83)$ was obtained from Zeolyst International and $\mathrm{NaY}_{\text {nano }}$ zeolite (NanoFAU$\mathrm{Y}, \mathrm{Si} / \mathrm{Al}=2.25$ ) from NanoScape. The zeolites were used after a thermal treatment at $120^{\circ} \mathrm{C}$ for $12 \mathrm{~h}$ in the oven. Silver nitrate $\left(\mathrm{AgNO}_{3}\right.$, Fisher Scientific), zinc nitrate $\left(\mathrm{Zn}\left(\mathrm{NO}_{3}\right)_{2} \cdot 4 \mathrm{H}_{2} \mathrm{O}\right.$, Merck), palladium nitrate $\left(\mathrm{Pd}\left(\mathrm{NO}_{3}\right)_{2} \cdot 2 \mathrm{H}_{2} \mathrm{O}\right.$, Aldrich) and copper nitrate $\left(\mathrm{Cu}\left(\mathrm{NO}_{3}\right)_{2} \cdot 3 \mathrm{H}_{2} \mathrm{O}\right.$, Riedel de Haen) were used as received.

\section{Catalysts Preparation}

Mono $(\mathrm{M})$ and bimetallic $\left(\mathrm{M}^{1} \mathrm{M}^{2}\right)$ catalysts based in $\mathrm{NaY}$ or $\mathrm{NaY}_{\text {nano }}$ zeolites were prepared by the ion-exchange method and further details can be found elsewhere. ${ }^{[22,23,25,26]}$ Briefly, the metal zeolite catalysts were prepared by this method and it can be schematized as follows [Eq. (1) and (2)]:

$\mathrm{Na}-\mathrm{ZEO}+\mathrm{M}^{1}\left(\mathrm{NO}_{3}\right) \rightarrow \mathrm{M}^{1} \mathrm{n}-\mathrm{ZEO}+\mathrm{Na}\left(\mathrm{NO}_{3}\right)$

where $M^{1}$ is the first metal exchanged and $M^{2}$ is the second metal introduced into $M^{1} n$-ZEO after the calcination step, $n$ is the salt concentration used and ZEO is $\mathrm{NaY}$ or $\mathrm{NaY}_{\text {nano. Twelve }}$ metal zeolite catalysts were studied: three $\mathrm{M}$ catalysts using a solution of $0.01 \mathrm{M}$ of the corresponding salt $(\mathrm{Cu}-\mathrm{Y}, \mathrm{Pd}-\mathrm{Y}$, $\mathrm{Cu}-\mathrm{Y}_{\text {nano }}$ ); four $\mathrm{M}^{1} \mathrm{M}^{2}$ catalysts ( $\mathrm{CuPd}-\mathrm{Y}, \mathrm{PdCu}-\mathrm{Y}, \mathrm{CuAg}-\mathrm{Y}$ and CuPd $\left.-Y_{\text {nano }}\right)$ by the introduction of the second metal $(0.01 \mathrm{M})$; three $\mathrm{M}^{1} \mathrm{M}^{2}$ catalysts $\left(\mathrm{CuPd}_{0.02}-\mathrm{Y}, \mathrm{PdCu}_{0.02}-\mathrm{Y}\right.$ and $\left.\mathrm{CuPd}_{0.02}-\mathrm{Y}_{\text {nano }}\right)$, with a solution of the second metal of $0.02 \mathrm{M}$; one $\mathrm{M}^{1} \mathrm{M}^{2}$ catalyst $\left(\mathrm{CuZn}_{0.05}-\mathrm{Y}\right)$ with a solution of $0.05 \mathrm{M}$ of zinc. Details about the sequence of the catalysts $(C u-Y, P d-Y, C u P d-Y$, $\mathrm{PdCu}-\mathrm{Y})$ and $\left(\mathrm{Cu}-\mathrm{Y}_{\text {nano, }}, \mathrm{CuPd}-\mathrm{Y}_{\text {nano, }}, \mathrm{CuPd}_{0.02}-\mathrm{Y}, \mathrm{PdCu}_{0.02}-\mathrm{Y}\right.$ and $\left.\mathrm{CuPd}_{0.02}-Y_{\text {nano }}\right)$ can be found in, ${ }^{[22,23]}$ respectively and for the $\mathrm{M}^{1} \mathrm{M}^{2}$ catalysts without metal noble in. ${ }^{[26]}$ In this work, the selectivity of the faujasite structure for the metal species was also studied. For such purpose a $\mathrm{M}^{1} \mathrm{M}^{2}$ catalyst $\left((\mathrm{CuPd})_{0.01}-\mathrm{Y}\right)$ was prepared by adding two simultaneous solutions $(0.01 \mathrm{M})$ of copper and palladium nitrate to the zeolite $\mathrm{NaY}$. The resulting metal zeolite catalyst was submitted to the same experimental conditions describe in. ${ }^{[22,23,25]}$

The metal zeolite catalysts were characterized by FTIR, $\mathrm{N}_{2}$ adsorption isotherms, TPR and chemical analysis. Sample preparation, analytical and instrumentation procedures of the metal zeolite catalysts are described in the supporting information and in. ${ }^{[22,23,25]}$

\section{Catalytic tests}

The catalytic oxidation of the volatile organic compounds was performed under atmospheric pressure in a fixed-bed reactor (U shape) with $6 \mathrm{~mm}$ of internal diameter, located inside a temperature-controlled electric furnace. To minimize thermal effects, $50 \mathrm{mg}$ of catalyst was blended with an inert (carborundum) of the same particle size as the catalyst $(0.2-0.5 \mathrm{~mm})$. Before the oxidation experiment, the catalyst was a pre-treated in air until $400^{\circ} \mathrm{C}$ for $1 \mathrm{~h}$. Then, the oxidation experiment was started using a VOC composition of $1000 \mathrm{mgC} / \mathrm{m}^{3}$ and a space velocity of $53050 \mathrm{~h}^{-1}$, in a total feed stream of $500 \mathrm{~cm}^{3}$ (STP)/ min. The temperature was increased at a rate of $2.5^{\circ} \mathrm{C} / \mathrm{min}$ between room temperature and $500^{\circ} \mathrm{C}$. The reaction was carried out in two cycles of increasing and decreasing temperature. The stability of the $(\mathrm{CuPd})_{0.01}-Y$ catalyst was assessed in a long-term experiment during $110 \mathrm{~h}$ at a temperature of $300^{\circ} \mathrm{C}$. The gas mixture at the reactor outlet was analyzed by a $\mathrm{CO}_{2}$ non-dispersive infrared (NDIR) sensor Vaisala GMT220 and a total volatile organic compound analyzer MiniRAE2000 (which has different sensitivity for each VOC). The conversion into $\mathrm{CO}_{2}$ $\left(X_{\mathrm{CO}_{2}}\right)$ was calculated as $X_{\mathrm{CO}_{2}}=F_{\mathrm{CO}_{2}} /\left(\nu \cdot F_{\mathrm{VOC}}\right.$, in , where $F_{\mathrm{VOC}}$, in is the inlet molar flow rate of VOC $\left(C_{V O C}\right.$, in is the corresponding concentration), $F_{V O C}$ is the outlet molar flow rate of $\mathrm{CO}_{2}$ and $v$ is the number of carbon atoms in the VOC molecule (for ethyl acetate, $v=4$ ).

\section{Acknowledgements}

This work has been developed under the scope of the projects: BioTecNorte (operation NORTE-01-0145-FEDER-000004) and "AlProcMat@N2020-Advanced Industrial Processes and Materials for a Sustainable Northern Region of Portugal 2020", NORTE-01-0145FEDER-000006, supported by the Northern Portugal Regional Operational Programme (NORTE 2020), under the Portugal 2020 Partnership Agreement, through the European Regional Development Fund (ERDF). This work also has been funded by national funds (FCT, Fundação para a Ciência e a Tecnologia), through the projects: PTDC/AAGTEC/5269/2014, Centre of Chemistry (UID/QUI) 00686/2013 and UID/QUI/0686/2016) and LSRE/LCM (POCI-010145-FEDER-006984).

\section{Conflict of Interest}

The authors declare no conflict of interest.

Keywords: VOC $\cdot$ Total oxidation $\cdot \mathrm{M}^{1} \mathrm{M}^{2} \cdot \mathrm{Y}$ Zeolite $\cdot$ ethy acetate

[1] M. S. Kamal, S. A. Razzak, M. M. Hossain, Atmos. Environ. 2016, 140, 117134.

[2] Y.-Suk Son, Chem. Eng. J. 2017, 316, 609-622.

[3] V. P. Santos, S. A. C. Carabineiro, P. B. Tavares, M. F. R. Pereira, J. J. M. Orfao, J. L. Figueiredo, Appl. Catal. B-Environ. 2010, 99, 198-205.

[4] W. B. Li, J. X. Wang, H. Gong, Catal. Today 2009, 148, 81-87. 
[5] S. A. C. Carabineiro, D. T. Thompson, in Nanocatalysis, (Eds.: E. U. Heiz, U. Landman), Springer-Verlag, Berlin, Heidelberg, New York, 2007, pp. 377-489.

[6] V. P. Santos, O. S. G.P. Soares, J. J. W. Bakker, M. F. R. Pereira, J. J. M. Orfao, J. Gascon, F. Kapteijn, J. L. Figueiredo, J. Catal. 2012, 293, 165174.

[7] M. A. Peluso, L. A. Gambaro, E. Pronsato, D. Gazzoli, H. J. Thomas, J. E. Sambeth, Catal. Today 2008, 133, 487-492.

[8] P. Papaefthimiou, T. loannides, X. E. Verykios, Appl. Catal. B-Environ 1997, 13, 175-184.

[9] H. L. Tidahy, S. Siffert, F. Wyrwalski, J. F. Lamonier, A. Aboukais, Catal. Today 2007, 119, 317-320.

[10] J. Tsou, P. Magnoux, M. Guisnet, J. J. M. Órfão, J. L. Figueiredo, Appl. Catal. B-Environ. 2005, 57, 117-123.

[11] C. T. Wong, A. Z. Abdullah, S. Bhatia, J. Hazard. Mater. 2008, 157, 480489.

[12] R. Beauchet, J. Mijoin, I. Batonneau-Gener, P. Magnoux, Appl. Catal. BEnviron. 2010, 100, 91-96.

[13] M. Gallastegi-Villa, M. Romero-Saez, A. Aranzabal, J. A. Gonzalez-Marcos, J. R. Gonzalez-Velasco, Catal. Today 2013, 213, 192-197.

[14] A. Corma, J. Catal. 2003, 216, 298-312.

[15] A. Corma, A. Martinez in Zeolites and ordered mesoporous materials: progress and prospects, (Eds.: J. Cejka, H. van Bekkum), Stud. Surf. Sci. Catal. Elsevier, Amsterdam, 2005, 157, pp 337-366.

[16] B. Silva, I. C. Neves, T. Tavares, Crit. Rev. Environ. Sci. Technol. 2016, 46:19-20, 1622-1657.

[17] B. Silva, H. Figueiredo, O. S. G. P. Soares, M. F. R. Pereira, J. L. Figueiredo, A. E. Lewandowska, M. A. Banares, I. C. Neves, T. Tavares, Appl. Catal. BEnviron. 2012, 117-118, 406-413.

[18] B. Silva, H. Figueiredo, V. P. Santos, M. F. R. Pereira, J. L. Figueiredo, A. E. Lewandowska, M. A. Banares, I. C. Neves, T. Tavares, J. Hazard. Mater. 2011, 192, 545-553.

[19] S. M. Seo, W. T. Lim, K. Seff, J. Phys. Chem. C 2012, 116, 963-974.

[20] Y. M. Lee, S. J. Choi, Y. Kim, K. Seff, J. Phys. Chem. B 2005, 109, 2013720144.
[21] B. Gu, L. Wang, S. Wang, D. Zhao, V. H. Rotberg, R. C. Ewing, J. Mater. Chem. 2000, 10, 2610-2616.

[22] O. S. G. P. Soares, L. Marques, C. M. A. S. Freitas, A. M. Fonseca, P. Parpot, J. J. M. Orfâo, M. F. R. Pereira, I. C. Neves, Chem. Eng. J. 2015, 281, 411417.

[23] O. S. G. P. Soares, C. M. A. S. Freitas, A. M. Fonseca, J. J. M. Órfão, M. F. R. Pereira, I. C. Neves, Chem. Eng. J. 2016, 291, 199-205.

[24] Y. Zhou, H. Zhang, Y. Yan, J. Taiwan, Inst. Chem. E 2018, 84, 162-172.

[25] C. M. A. S. Freitas, O. S. G. P. Soares, J. J. M. Órfão, A. M. Fonseca, M. F. R. Pereira, I. C. Neves, Green Chem. 2015, 17, 4247-4254.

[26] L. Ferreira, C. Almeida-Aguiar, P. Parpot, A. M. Fonseca, I. C. Neves, RCS Adv. 2015, 5, 37188-37195.

[27] W. Lutz, C. H. Ruscher, D. Heidemann, Micropor. Mesopor. Mat. 2002, 55, 193-202.

[28] O. S. G. P. Soares, J. J. M. Orfao, J. Ruiz-Martinez, J. Silvestre-Albero, A Sepulveda- Escribano, M. F. R. Pereira, Chem. Eng. J. 2010, 165, 78-88.

[29] C. M. Mendez, H. Olivero, D. E. Damiani, M. A. Volpe, Appl. Catal. BEnviron. 2008, 84, 156-161.

[30] M. Jablonska, A. Krol, E. Kukulska-Zajac, K. Tarach, V. Girman, L. Chmielarz, K. Gora-Marek, Appl. Catal. B-Environ. 2015, 166, 353-365.

[31] P. O. Larsson, A. Andersson, L. R. Wallenberg, B. Svensson, J. Catal. 1996, 163, 279-293.

[32] R. Brayner, D. D. Cunha, F. Bozon-Verduraz, Catal. Today 2003, 78, 419432.

[33] A. Jodaei, D. Salari, A. Niaei, M. Khatamian, N. Caylak, Environ. Technol. 2011, 32, 395-406.

Manuscript received: May 28, 2018

Accepted Article published: July 6, 2018

Version of record online: August 1, 2018 